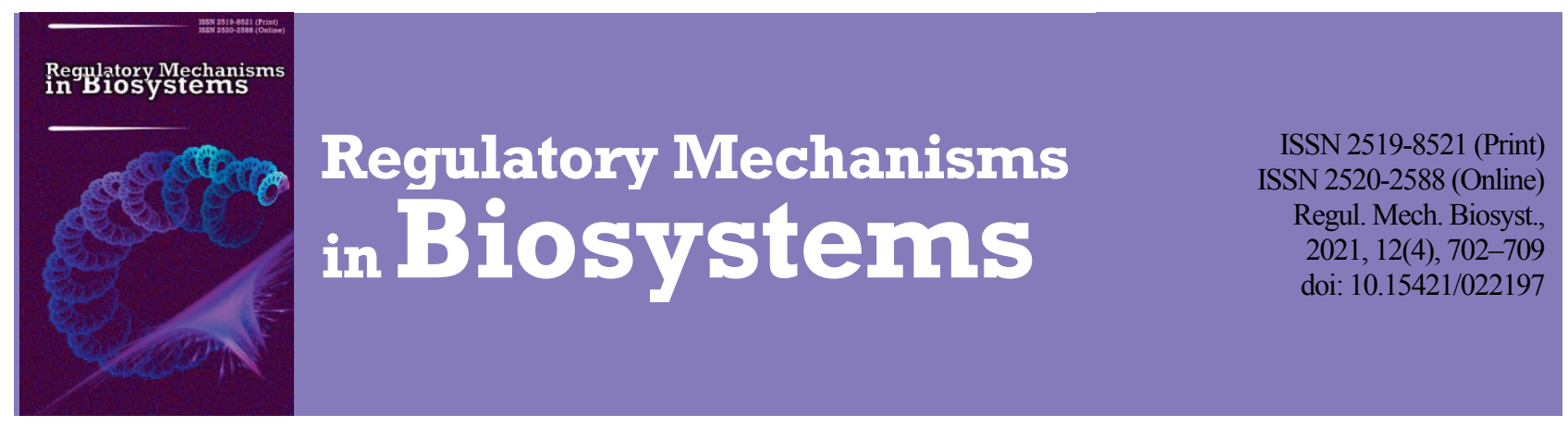

\title{
Specifics of the morphological identification of the pathogen of passaluariasis of rabbits
}

\author{
A. Khorolskyi*, V. Yevstafieva*, S. Kravchenko*, M. Pishchalenko*, Y. Vakulenko*, B. Gutyj** \\ *Poltava State Agrarian University, Poltava, Ukraine \\ **Lviv National University of Veterinary Medicine and Biotechnologies named after S. Z. Gzhytskyj, Lviv, Ukraine
}

Article info

Received 10.10.2021

Received in revised form 05.11 .2021

Accepted 07.11.2021

Poltava State Agrarian

University, Skovorody st.

1/3, Poltava,

36003, Ukraine

Tel.: +38-050-183-78-78.

E-mail:evstva@ukr.net

Lviv National University

of Veterinary Medicine

and Biotechnologies

named after S. Z. Gzhyts-

kvj. Pekarska st., 50,

Lviv, 79000, Ukraine.

Tel.: +38-068-136-20-54

E-mail:bvh@ukr.net

\begin{abstract}
Khorolskyi, A., Yevstafieva, V., Kravchenko, S., Pishchalenko, M., Vakulenko, Y., \& Gutyj, B. (2021). Specifics of the morphological identification of the pathogen of passaluariasis of rabbits. Regulatory Mechanisms in Biosystems, 12(4), 702-709. doi:10.15421/022197
\end{abstract}

Passalurus ambiguus (Nematoda, Oxyuroidae) is one of the most common parasites of digestive tract of domestic and wild rabbits and rodents. Passalurus spp. are cosmopolitan, and the mature nematodes are localized in the appendages and large intestine of animals. The passaluariasis infections remain quite relevant in modern rabbit breeding, because the disease is highly contagious, with the possibility of unlimited spread inducing significant economic losses. The aim of the study was to determine the identifying morphological species characteristics of P. ambiguus nematodes, which were isolated from the colon of domestic rabbits (Oryctolagus cuniculus domesticus). The identifying characters of Passalurus include morphological features, namely the presence of a spherical bulb in the esophagus, and the presence of three teeth in the oral capsule. Males of $P$. ambiguus have a characteristic structure of the tail end, namely the presence of papillary protrusions and a massive narrowed part with a spicule handle, and five papillae around the cloaca. Twenty-eight metric indicators are proposed that characterize the size of the body, oral capsule, esophagus in different parts of it, the tail end, spicules, the location of the cloaca. Two different morphotypes of mature females of $P$. ambiguus were revealed - short-tailed and long-tailed, which were larger by 19 indicators (by 3.2-43.6\%). The morphotypes of $P$. ambiguus females are characterized; the length of the tail, body length and width in different areas, depth of the oral capsule, esophageal size and its structural elements, the location of the vulva and nerve ring, the width of the caudal process. At the same time, the parameters of esophageal bulb length and caudal process in short-tailed females were higher (by $13.9 \%$ and $11.9 \%$, respectively) than in the long-tailed females. A total of 25 morphometric parameters were proposed for the identification of $P$. ambiguus females. The obtained data indicate the feasibility of further research on the causes of occurrence of such morphotypes in $P$. ambiguus females and the need to take into account the existence of such forms of females for their differential diagnosis taking into account their proposed morphometric parameters.

Keywords: Passalurus ambiguus; parasitic nematodes; diagnostics; differential characters

\section{Introduction}

In some countries, rabbit breeding is a promising livestock industry that produces raw materials and a variety of products for food and light industry, crop production and medicine. The potential of this industry lies in the fast production and relatively low cost of keeping the animals (Dalle Zotte, 2014; Cullere \& Dalle Zotte, 2018; Li et al., 2018). The development of that industry is restrained by diseases of parasitic etiology, among which passaluriasis occupies a dominant place as a highly contagious infection with the possibility of unlimited spread among susceptible rabbits. The spread of passaluriasis is facilitated by unsanitary conditions associated with keeping rabbits on unchanged litter or at high densities (Foronda et al., 2003; Rinaldi et al., 2007; Eira et al., 2007). Thus, the parasites cause significant economic loss to the industry, consisting of live weight loss, reduced fattening of rabbit carcasses, and reduced meat quality (Madsen, 1986; Hobbs et al., 1999).

The rates of prevalence of $P$. ambiguus in rabbits ranged from $0.8 \%$ to $54.0 \%$ in Iran (Eslami et al., 2000; Yagoob \& Hossein, 2011; Motamedi et al., 2014; Hajipour \& Zavarshani, 2020). In Germany, the infection rates of wild rabbits with the pathogen reached $68.0 \%$ (Frank et al., 2013). In Serbia, passaluriasis was diagnosed in $17.1 \%$ of studied domestic rabbits (Ilić et al., 2018). In Egypt this figure reached 40.0\%, and young animals were more susceptible to passaluriasis than adult rabbits (Ashmawy et al., 2010). In Scotland, the rates of infection by $P$. ambiguus was found to be $0.5 \%$ in hares and $54.0 \%$ in domestic rabbits (Boag \& Iason, 1986).
In Poland, passaluriasis was detected in all studied rabbit farms, with a prevalence of $14.1 \%$ to $27.5 \%$ (Nosal et al., 2009). In Chile, in the study of grey hares (Lepus europaeus), the rates of infection of passaluriasis was 5.0\% (González-Acuña et al., 2005).

Such a significant spread of passaluriasis is facilitated by the developed coprophagy, which is a common physiological process in rabbits. Moreover, the eating occurs directly from the anus, where the number of parasite eggs is largest (Ebino et al., 1993; Kornaś et al., 2015). The cycle of development of the parasite is another favourable factor for the rapid spread of the infection. The development occurs via the direct oxyurid type (Danheim \& Ackert, 1929; Yevstafieva et al., 2020). The postembryonic stages occur in the host's body, and embryonic stages develop partly on it, partly in the environment. In particular, female $P$. ambiguus nematodes lay eggs on the skin around the anus. At the gastrula stage, the eggs enter the environment and contaminate it. Moreover, eggs can develop at a temperature of $25-40^{\circ} \mathrm{C}$ (optimal temperature $+35-38^{\circ} \mathrm{C}$ ) to the infectious stage within 7-8 days. Rabbits become infected by swallowing invasive eggs, mainly during coprophagy (Skjabin et al., 1967; Taffs, 1976; Fayek et al., 1995).

Therefore, due to the high prevalence of passaluriasis in the population of both domestic and wild rabbits and hares, the species identification of these parasitic nematodes is very important (Hugot et al., 1982; Pinto et al., 2004; Sultan et al., 2015). Scanning electron microscopy (SEM) has been used to determine the morphological features of nematodes of the species $P$. ambiguus. Also, SEM is useful in the differentiation of $P$. am- 
biguus and $P$. nonanulatus by features in the location of amphids and the structure of the head end (Hugot et al., 1982; Bin \& Chunsheng, 1987). Other authors propose using ultrastructural features of the cuticle and intestinal wall, namely the number of cuticular sublayers in the anterior, central and posterior parts of the body of nematodes and the absence of the basal cuticular membrane for species differentiation (Georgieva et al., 2005). Molecular genetic methods are also applied for species identification of nematodes of the genus Passalurus (Li et al., 2014; Sheng et al., 2014). At the same time, many authors suggest that the determination of the species of Passalurus mainly depends on the use of conventional methods of microscopic examination of the morphology of nematodes (Pinto et al., 2004).

Thus, the pathogen of passaluriasis is studied in many countries in order to enhance identification by species characteristics, which is relevant for timely and accurate diagnosis of the disease, the evaluation of the adaptive properties of the pathogen and the application of effective control measures.

The aim of the study was to study the identifying morphological species characteristics of $P$. ambiguus nematodes isolated from the colon of domestic rabbits.

\section{Materials and methods}

The research was conducted during 2020-2021 in the laboratory of the Department of Parasitology and Veterinary Sanitary Examination of Poltava State Agrarian University (Poltava) on the basis of private and large rabbit farms. The helminths were obtained by complete helminthological dissection of the colon of 63 killed rabbits, Oryctolagus cuniculus domesticus (Skriabyn, 1928). After isolation of helminths from the intestine, they were washed in distilled water, then fixed with 70\% ethyl alcohol (Ivashkin et al., 1971). Species identification of Passalurus was performed by the morphological structure according to keys (Skjabin et al., 1967; Gvozdev et al., 1970). In total, 948 nematodes of P. ambiguus were collected, of which: 223 males and 724 females (478 short-tailed, 246 long-tailed).
The morphometric parameters of adult males and females of nematodes of $P$. ambiguus were determined using ImageJ for Windows ${ }^{\circledR}$ software (version 2.00) in interactive mode using a lens $\times 5, \times 10, \times 40$ and a photo eyepiece $\times 10$. Microphotography was performed using digital camera to the microscope Sigeta M3CMOS 14000 14.0 MP (China).

Standard deviation (SD) and average values (x) were calculated. Significance of difference between average values in the studied $P$. ambiguus females of two different morphological types was established using oneway analysis of variance and F-test for $95 \%$ confidence level.

\section{Results}

The nematodes of this species were small, spindle-shaped with tapering ends. The tail end was thinner than the anterior. Males were much smaller than females (Fig. 1a). The mouth was surrounded by four large papillae. The oral capsule was small, with three well-defined teeth at the bottom (Fig. 1b). The head end contained narrow lateral wings, which had a wavy structure. The anterior edges of wings were located at a small distance from the head end, narrowed to the end of the esophagus and continued along the body as a narrow ribbon. The esophagus showed a structure characteristic of oxyurids, namely: it gradually expands, then sharply narrows and turns into a well-defined spherical bulb. The latter, also in its posterior part, is constricted at the connection with the intestine (Fig. 1c). Males of P. ambiguus were small, with a hook-shaped body (Fig. 2a). At the tail end there were small, narrow, lateral cuticular wings, which ended on two large and well-defined papillary projections. In that area, the tail narrowed sharply and continued with a thin tip. The cloaca was surrounded by five well-defined papillae (Fig. 2b). There was one massive short spicule, expanded in the proximal part in the form of a handle. The proximal part of spicule was well separated by a significant narrowing. The distal part of the spicule was narrowed and pointed (Fig. 2c, 2d).

The analysis of obtained data on the metric features of $P$. ambiguus males revealed 28 differential parameters. At the same time, the number of parameters proposed by other authors for the differential diagnosis of P. ambiguus males ranged from 1 to 10 (Table 1 ).

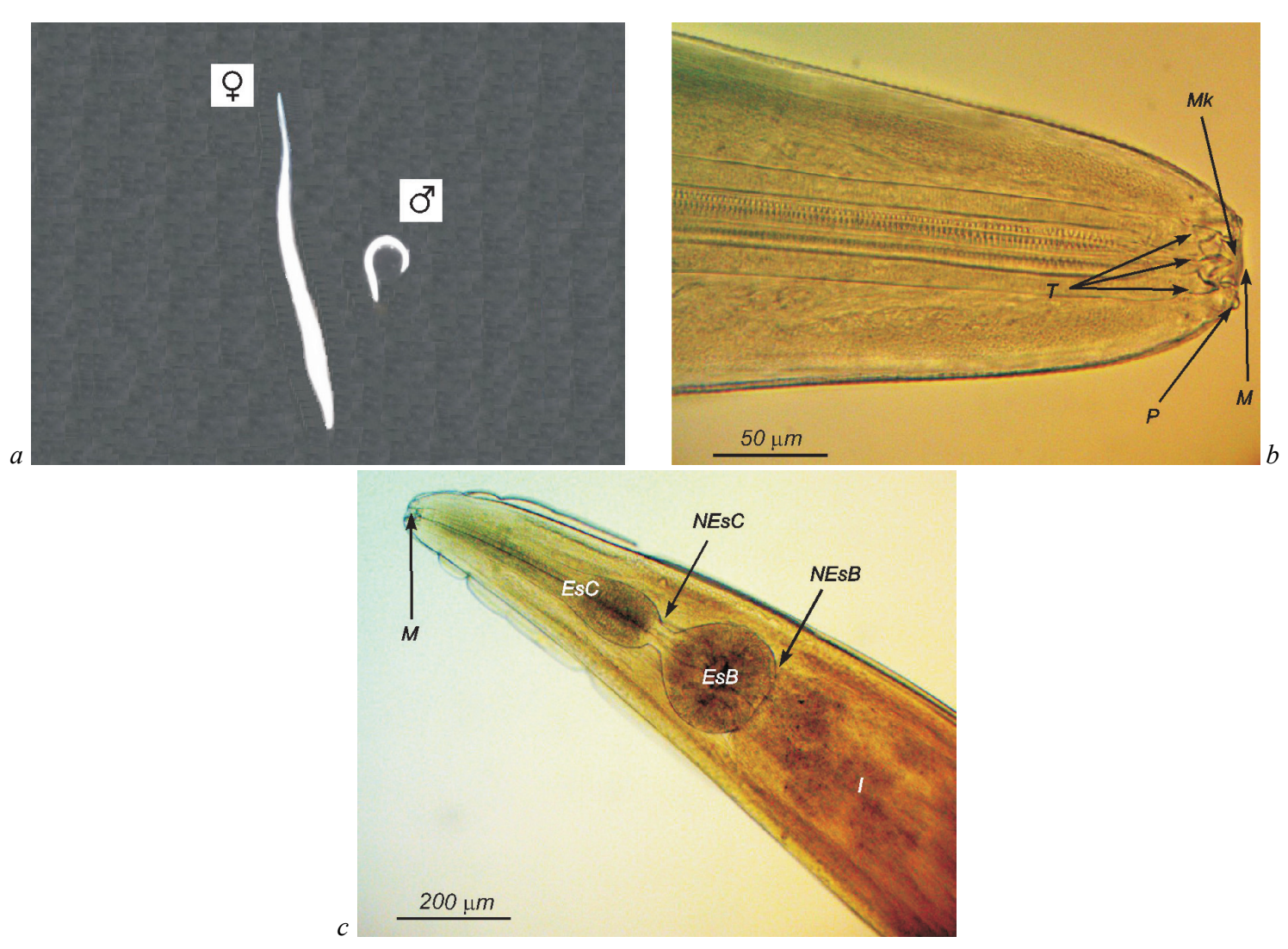

Fig. 1. Body structure of nematodes of the species Passalurus ambiguus:

$a$-general view of males and females; $b$ - mouth $(M)$, mouth capsule $(M k)$, teeth $(T)$, papillae $(P) ; c$-cylindrical part of the esophagus $(E s C)$, narrow part at the end of the cylindrical part of the esophagus (NEsC), bulbus (EsB), narrow part at the end of the bulb (NEsB), intestine (I) 


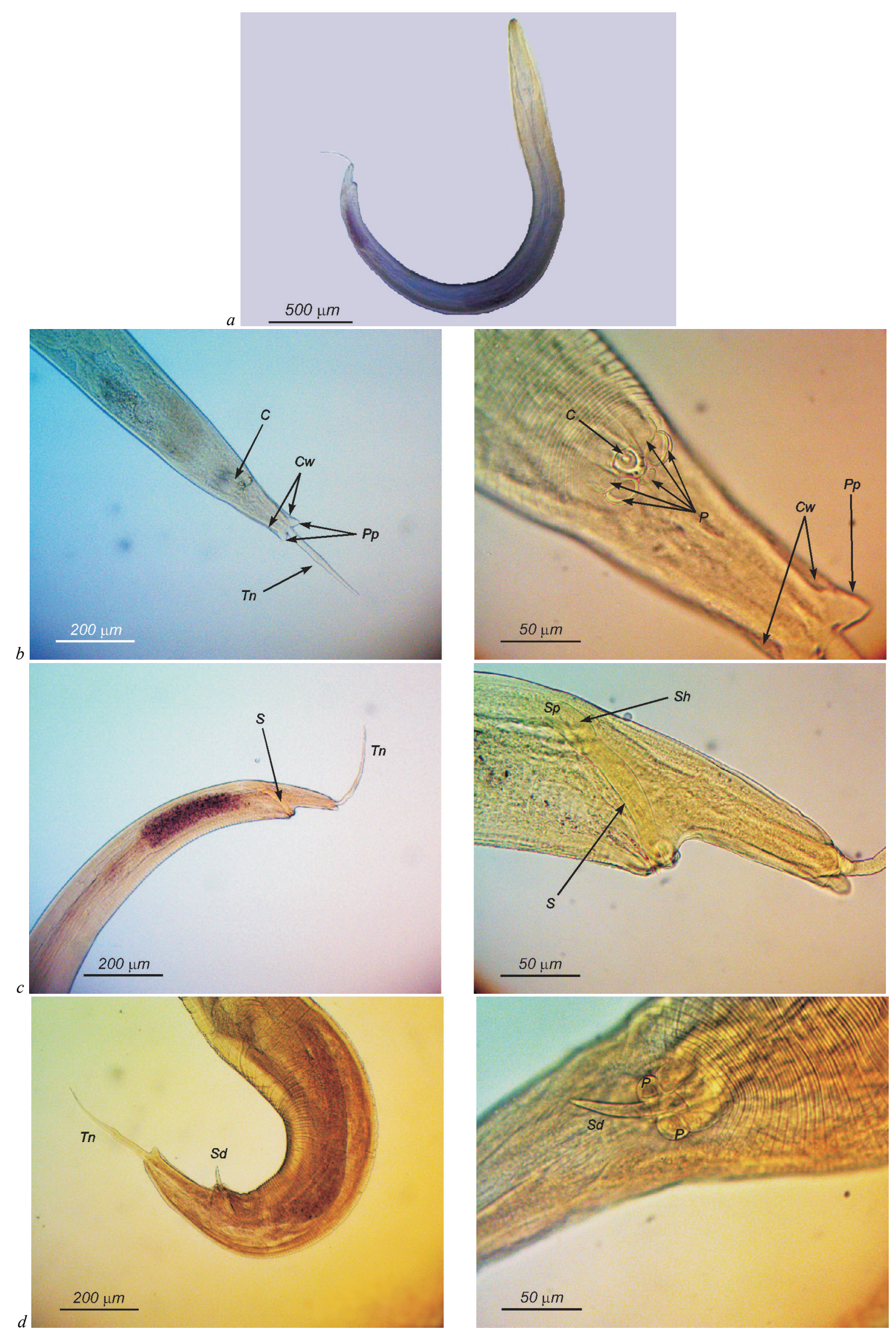

Fig. 2. The structure of males Passalurus ambiguus: $a$-general view; $b$ - the tail end; $c$-structure and location of the spicule in the body cavity; $d$-structure and location of the spicule in the protruded state; $C w$-cuticular wings, $P p$-papillary protrusions, $T n$-narrowed part of the tail, $S$-spicule, $S d$-distal end of the spicule, $S p$ - proximal end of the spicule, $S h$-spicule handle, $C$-cloaca, $P$-papillae 
Table 1

Comparative analysis of morphometric characters of male Passalurus ambiguus ( $\mathrm{n}=15, \mathrm{x} \pm \mathrm{SD}, \min -\max )$

\begin{tabular}{|c|c|c|c|c|c|c|c|}
\hline Parameter & $\begin{array}{c}\text { Own } \\
\text { specimens }\end{array}$ & $\begin{array}{l}\text { Hall, } \\
1916\end{array}$ & $\begin{array}{c}\text { Skryabin } \\
\text { et al., } 1960\end{array}$ & $\begin{array}{l}\text { Gvozdev } \\
\text { et al., } 1970\end{array}$ & $\begin{array}{c}\text { Hugot } \\
\text { et al., } 1983\end{array}$ & $\begin{array}{l}\text { Frank } \\
\text { et al., } 2013\end{array}$ & $\begin{array}{l}\text { Mykhailiutenko } \\
\text { et al., } 2019\end{array}$ \\
\hline Length of body, mm & $\begin{array}{l}5.05 \pm 0.63 \\
3.61-6.14\end{array}$ & $4.3-5.0$ & $3.8-5.0$ & $3.8-5.0$ & 4.5 & $\begin{array}{c}4.80 \\
4.26-4.97\end{array}$ & $\begin{array}{c}4.6 \pm 0.4 \\
3.94-5.12\end{array}$ \\
\hline Depth of oral capsule, $\mu \mathrm{m}$ & $\begin{array}{l}12.11 \pm 1.36 \\
10.23-15.32\end{array}$ & - & - & - & - & - & - \\
\hline Distance from head end to nerve ring, $\mu \mathrm{m}$ & $\begin{array}{l}150.69 \pm 13.69 \\
133.00-174.87\end{array}$ & $150-175$ & $150-175$ & - & 140 & - & - \\
\hline Width of body, $\mu \mathrm{m}$, at: & & & & & & & \\
\hline - bottom of oral capsule & $\begin{array}{l}54.80 \pm 4.17 \\
49.24-62.07\end{array}$ & - & - & - & - & - & - \\
\hline - nerve ring & $\begin{array}{c}125.47 \pm 8.73 \\
110.27-140.28\end{array}$ & - & - & - & - & - & - \\
\hline $\begin{array}{l}\text { - narrowed end of cylindrical part of eso- } \\
\text { phagus }\end{array}$ & $\begin{array}{l}190.37 \pm 12.95 \\
168.22-209.34\end{array}$ & - & - & - & - & - & - \\
\hline - narrowed end part of the bulb & $\begin{array}{l}226.29 \pm 24,36 \\
197.00-285.22\end{array}$ & - & - & - & - & - & - \\
\hline - cloaca & $\begin{array}{l}104.73 \pm 11.15 \\
87.13-121.03\end{array}$ & - & - & - & - & - & - \\
\hline - papillary protrusions at tail end & $\begin{array}{l}66.54 \pm 3.31 \\
60.12-72.15\end{array}$ & - & - & - & - & - & - \\
\hline Maximum width of body, $\mu \mathrm{m}$ & $\begin{array}{l}302.19 \pm 34.97 \\
189.33-334.45\end{array}$ & $240-275$ & $232-275$ & $232-275$ & 150 & - & $\begin{array}{l}257.4 \pm 17.8 \\
232-281\end{array}$ \\
\hline \multicolumn{8}{|l|}{ Esophagus, $\mu \mathrm{m}$ : } \\
\hline - total length & $\begin{array}{l}575.02 \pm 17.44 \\
545.58-594.18\end{array}$ & - & $482-564$ & - & 560 & - & - \\
\hline - length of cylindrical part & $\begin{array}{l}424.09 \pm 15.37 \\
403.25-459.38\end{array}$ & $370-412$ & - & - & - & - & - \\
\hline - width of cylindrical part in the middle & $\begin{array}{l}42.39 \pm 2.18 \\
39.45-45.66\end{array}$ & $60-70$ & - & - & - & - & - \\
\hline - maximum width of cylindrical part & $\begin{array}{l}90.44 \pm 3.14 \\
83.64-95.62\end{array}$ & - & - & - & - & - & - \\
\hline $\begin{array}{l}\text { - width of the narrowed end of cylindrical } \\
\text { part of esophagus }\end{array}$ & $\begin{array}{l}31.92 \pm 2.45 \\
28.14-36.33\end{array}$ & - & - & - & - & - & - \\
\hline $\begin{array}{l}\text { - length of the narrowed end of cylindrical } \\
\text { part of esophagus }\end{array}$ & $\begin{array}{l}20.01 \pm 1.67 \\
17.88-24.12\end{array}$ & - & - & - & - & - & \\
\hline - length of the bulb & $\begin{array}{l}130.92 \pm 23.00 \\
102.50-165.71\end{array}$ & $120-130$ & $120-160$ & - & - & - & - \\
\hline - width of the bulb & $\begin{array}{l}150.61 \pm 14.29 \\
122.54-176.33\end{array}$ & $112-125$ & $112-164$ & - & - & - & - \\
\hline $\begin{array}{l}\text { - ratio of length of cylindrical part of eso- } \\
\text { phagus to length of bulb }\end{array}$ & $2.85: 1$ & - & - & - & - & - & - \\
\hline Distance from head end to cloaca, $\mathrm{mm}$ & $\begin{array}{c}4.65 \pm 0.63 \\
3.24-5.75\end{array}$ & - & - & - & - & - & - \\
\hline Distance from cloaca to tail end, $\mathrm{mm}$ & $\begin{array}{l}405.46 \pm 25.47 \\
370.29-468.19\end{array}$ & $370-410$ & $370-415$ & $370-415$ & - & - & - \\
\hline Length of narrowed part of tail end, $\mu \mathrm{m}$ & $\begin{array}{l}279.24 \pm 14.12 \\
250.14-294.85\end{array}$ & $225-260$ & - & $158-265$ & 300 & - & $\begin{array}{c}221.2 \pm 35.2 \\
168-269\end{array}$ \\
\hline $\begin{array}{l}\text { Width of narrowed part of tail end at the area } \\
\text { of papillary protrusions, } \mu \mathrm{m}\end{array}$ & $\begin{array}{l}25.51 \pm 1.85 \\
22.05-28.02\end{array}$ & - & $14-15$ & - & - & - & - \\
\hline $\begin{array}{l}\text { Length of narrowed part of tail end in the } \\
\text { middle, } \mu \mathrm{m}\end{array}$ & $\begin{array}{l}14.75 \pm 1.38 \\
12.19-16.24\end{array}$ & - & - & - & - & - & - \\
\hline Length of spicule, $\mu \mathrm{m}$ & $\begin{array}{c}140.51 \pm 6.67 \\
126.44-150.34\end{array}$ & $90-120$ & $90-134$ & $90-134$ & 125 & - & $\begin{array}{c}119.9 \pm 12.9 \\
89-137\end{array}$ \\
\hline Length of the handle of spicule, $\mu \mathrm{m}$ & $\begin{array}{l}39.52 \pm 2.43 \\
35.05-45.18\end{array}$ & - & - & - & - & - & - \\
\hline Width of proximal end of spicule, $\mu \mathrm{m}$ & $\begin{array}{l}20.13 \pm 2.05 \\
16.22-22.47\end{array}$ & - & - & - & - & - & - \\
\hline Width of distal end of spicule, $\mu \mathrm{m}$ & $\begin{array}{l}11.91 \pm 1.17 \\
10.05-13.84\end{array}$ & - & - & - & - & - & - \\
\hline
\end{tabular}

Note: “-"-parameters were not defined.

Thus, the proposed characters of males include the total body length, the distance from the head end to the nerve ring, the maximum width of the body, the total length of the esophagus, the length and width of its parts (cylindrical and bulbous), the distance from the cloaca to the tail end, length of the narrowed part of the tail in the area of the papillary protrusions and the total length of the spicule. We additionally proposed using metric parameters for the identification of male $P$. ambiguus, which characterize the depth of the oral capsule, body width in different parts of the body (six parameters), structure of esophagus, location of the cloaca relative to the head end, shape of proximal and distal spicule ends and its handles. Females of $P$. ambiguus, in contrast to males, were much larger (2.0-2.5 times) and had a straight body (Fig. 1a). The vulva was located in the anterior part of body. The hole of vulva was transverse, slit-like, long, weakly expressed, did not stand out above the cuticle surface. The vagina was wide, long, well defined, directed backwards. The vulva was surrounded with well-developed verrucose formations, the number of which in mature females with eggs ranged from 9 to 12 (Fig. 3a). The uterus was densely filled with oxyurid-type eggs - asymmetric, as if pressed on one side, with a well-defined shell (Fig. 3b). We found two morphotypes of females that were characterized by different tail lengths - short (Fig. 3c) and long (Fig. 3d). The general morphological structure of the tail end was the same. It was gradually tapering and covered with bead-like thickenings, at the end sharply narrowed into a very thin caudal process (Fig. 3c, 3d).

Analysis of the obtained data on the metric parameters of $P$. ambiguus females revealed 25 indicative parameters. Other authors proposed from one to eight such parameters for the differential diagnosis of $P$. ambiguns females (Table 2). 


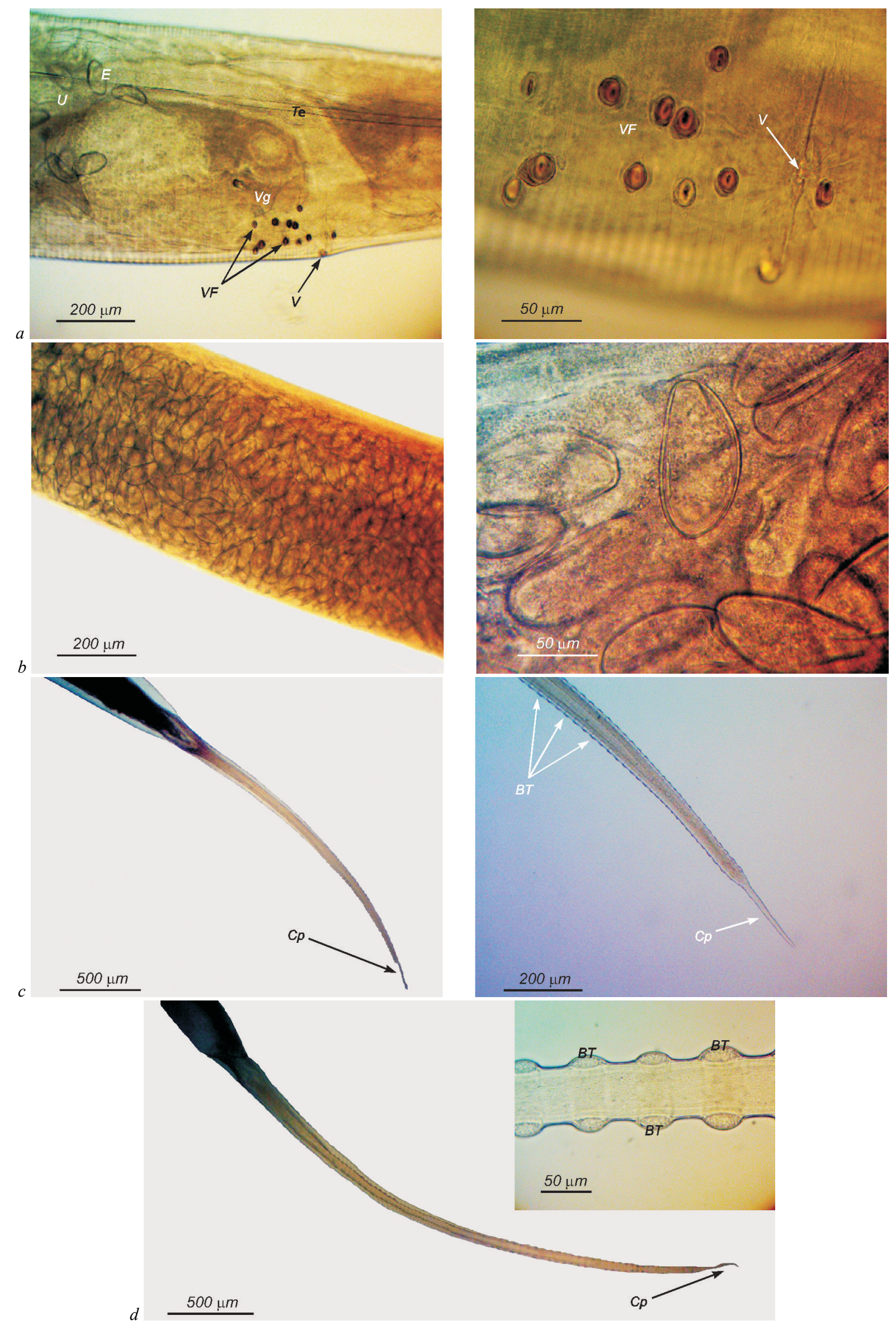

Fig. 3. The structure of females Passalurus ambiguus:

$a$-vulva; $b$ - the uterus is filled with eggs; $c$ - the tail end of short-tailed females; $d$-the tail end of long-tailed females;

$V$-vulva, $V g$-vagina, $V F$-verrucose formations, $U$-uterus, $T e$-tubular egg, $E$-eggs, $C p$-caudal process, $B T$-bead-like thickenings 
Table 2

Comparative analysis of morphometric characters of female Passalurus ambiguus ( $\mathrm{n}=15, \mathrm{x} \pm \mathrm{SD}, \min -\max )$

\begin{tabular}{|c|c|c|c|c|c|c|c|c|}
\hline \multirow{2}{*}{ Parameter } & \multicolumn{2}{|c|}{ Present specimens } & \multirow{2}{*}{$\begin{array}{l}\text { Hall, } \\
1916\end{array}$} & \multirow{2}{*}{$\begin{array}{l}\text { Skryabin } \\
\text { et al., } 1960\end{array}$} & \multirow{2}{*}{$\begin{array}{l}\text { Gvozdev } \\
\text { et al., } 1970\end{array}$} & \multirow{2}{*}{$\begin{array}{c}\text { Hugot } \\
\text { et al., } 1983\end{array}$} & \multirow{2}{*}{$\begin{array}{c}\text { Frank } \\
\text { et al., } 2013\end{array}$} & \multirow{2}{*}{$\begin{array}{l}\text { Mykhailiutenko } \\
\text { et al., } 2019\end{array}$} \\
\hline & short-tailed & long-tailed & & & & & & \\
\hline Length of body, $\mathrm{mm}$ & $\begin{array}{c}10.08 \pm 0.81 \\
8.98-11.34\end{array}$ & $\begin{array}{c}12.46 \pm 0.53 * * * \\
11.63-13.35\end{array}$ & $9-11$ & $7.75-11.00$ & $7.75-11.00$ & $8.2-11.0$ & $\begin{array}{c}10.6 \\
8.32-11.00\end{array}$ & $\begin{array}{c}9.7 \pm 1.2 \\
7.87-11.20\end{array}$ \\
\hline Depth of oral capsule, $\mu \mathrm{m}$ & $\begin{array}{l}17.02 \pm 1.49 \\
14.25-19.33\end{array}$ & $\begin{array}{c}22.15 \pm 1.28 * * * \\
20.17-24.23\end{array}$ & - & - & - & - & - & - \\
\hline $\begin{array}{l}\text { Distance from head end to nerve } \\
\text { ring, } \mu \mathrm{m} \\
\text { Width of body, } \mu \mathrm{m} \text {, at: }\end{array}$ & $\begin{array}{c}174.43 \pm 9.96 \\
150.33-190.42\end{array}$ & $\begin{array}{c}245.65 \pm 21.17 \text { *** } \\
217.58-285.13\end{array}$ & $190-215$ & $187-215$ & - & $210-325$ & - & - \\
\hline - bottom of oral capsule & $\begin{array}{l}72.11 \pm 2.22 \\
70.14-78.05\end{array}$ & $\begin{array}{c}89.95 \pm 3.38 * * * \\
82.17-96.15\end{array}$ & - & - & - & - & - & - \\
\hline - nerve ring & $\begin{array}{l}152.51 \pm 11.49 \\
133.60-170.90\end{array}$ & $\begin{array}{c}186.71 \pm 4.22 * * * \\
179.56-192.17\end{array}$ & - & - & - & - & - & - \\
\hline $\begin{array}{l}\text { - narrowed end of cylindrical part } \\
\text { of esophagus }\end{array}$ & $\begin{array}{l}288.93 \pm 11.38 \\
270.31-306.43\end{array}$ & $\begin{array}{c}303.12 \pm 10.44 * * * \\
287.12-319.45\end{array}$ & - & - & - & - & - & - \\
\hline - narrowed end part of the bulb & $\begin{array}{l}370.97 \pm 13.12 \\
350.24-394.10\end{array}$ & $\begin{array}{c}394.33 \pm 11.20 * * * \\
364.48-409.43\end{array}$ & - & - & - & - & - & - \\
\hline -vulva & $\begin{array}{l}547.96 \pm 26.48 \\
493.22-581.12\end{array}$ & $\begin{array}{c}694.96 \pm 11.79 * * * \\
667.12-711.15\end{array}$ & $551-990$ & - & - & - & - & - \\
\hline- anus & $\begin{array}{l}186.24 \pm 15.14 \\
167.53-220.06\end{array}$ & $\begin{array}{c}215.89 \pm 15.74 * * * \\
179.50-239.02\end{array}$ & - & - & - & - & - & - \\
\hline Maximum width of body, $\mu \mathrm{m}$ & $\begin{array}{l}635.15 \pm 28.01 \\
602.16-680.17\end{array}$ & $\begin{array}{l}751.57 \pm 26.71 * * * \\
718.04-822.21\end{array}$ & - & $464-590$ & $464-590$ & $550-650$ & - & $\begin{array}{c}546.2 \pm 37.1 \\
479-592\end{array}$ \\
\hline $\begin{array}{l}\text { Esophagus, } \mu \mathrm{m}: \\
\text { - total length }\end{array}$ & $\begin{array}{l}702.52 \pm 19.88 \\
674.98-737.03\end{array}$ & $\begin{array}{c}725.77 \pm 19.95 * * \\
687.24-761.01\end{array}$ & - & $495-713$ & - & $600-700$ & - & - \\
\hline - length of cylindrical part & $\begin{array}{l}462.55 \pm 18.90 \\
423.11-498.18\end{array}$ & $\begin{array}{c}504.96 \pm 18.83 * * * \\
454.64-533.07\end{array}$ & $495-535$ & - & - & - & - & - \\
\hline $\begin{array}{l}\text { - width of cylindrical part in the } \\
\text { middle }\end{array}$ & $\begin{array}{l}51.65 \pm 2.31 \\
48.25-56.33\end{array}$ & $\begin{array}{l}53.12 \pm 2.93 \\
49.04-58.04\end{array}$ & $68-80$ & - & - & - & - & - \\
\hline $\begin{array}{l}\text { - maximum width of cylindrical } \\
\text { part }\end{array}$ & $\begin{array}{l}104.54 \pm 3.97 \\
98.24-110.85\end{array}$ & $\begin{array}{c}116.64 \pm 5.44 * * * \\
108.45-124.12\end{array}$ & - & - & - & - & - & - \\
\hline $\begin{array}{l}\text { - width of the narrowed end of } \\
\text { cylindrical part of esophagus }\end{array}$ & $\begin{array}{l}39.76 \pm 1.35 \\
37.22-41.52\end{array}$ & $\begin{array}{c}40.10 \pm 2.36 \\
33.45-4.12\end{array}$ & - & - & - & - & - & - \\
\hline $\begin{array}{l}\text { - length of the narrowed end of } \\
\text { cylindrical part of esophagus }\end{array}$ & $\begin{array}{l}28.90 \pm 2.80 \\
22.41-33.71\end{array}$ & $\begin{array}{c}39.26 \pm 1.03 * * * \\
37.33-41.05\end{array}$ & - & - & - & - & - & - \\
\hline - length of bulb & $\begin{array}{l}211.08 \pm 16.24 \\
184.67-238.26\end{array}$ & $\begin{array}{c}181.55 \pm 21.81 * * * \\
155.86-221.23\end{array}$ & - & - & - & - & - & - \\
\hline - width of bulb & $\begin{array}{c}201.50 \pm 5.57 \\
190.34-209.45\end{array}$ & $\begin{array}{c}208.61 \pm 8.13 * * \\
190.55-221.57\end{array}$ & - & - & - & - & - & - \\
\hline $\begin{array}{l}\text {-ratio of length of cylindrical part } \\
\text { of esophagus to length of bulb }\end{array}$ & $2.21: 1$ & $2.82: 1$ & - & - & - & - & - & - \\
\hline $\begin{array}{l}\text { Distance from vulva to head end, } \\
\mathrm{mm}\end{array}$ & $\begin{array}{c}1.70 \pm 0.09 \\
1.53-1.89\end{array}$ & $\begin{array}{l}1.92 \pm 0.06 * * * \\
1.78-1.99\end{array}$ & $1.54-1.89$ & $1.54-1.89$ & $1.54-1.89$ & $1.35-1.05$ & - & - \\
\hline Distance from vulva to anus, mm & $\begin{array}{c}6.20 \pm 0.78 \\
5.17-7.20\end{array}$ & $\begin{array}{c}6.69 \pm 0.64 \\
5.23-7.62\end{array}$ & - & - & - & - & - & - \\
\hline $\begin{array}{l}\text { Distance from vulva to tail end, } \\
\mathrm{mm}\end{array}$ & $\begin{array}{c}8.37 \pm 0.80 \\
7.33-9.65\end{array}$ & $\begin{array}{c}10.54 \pm 0.50 * * * \\
9.85-11.40\end{array}$ & - & - & - & - & - & $\begin{array}{c}0.181 \\
0.161-0.194\end{array}$ \\
\hline Length of tail end, mm & $\begin{array}{c}2.17 \pm 0.20 \\
1.74-2.45\end{array}$ & $\begin{array}{c}3.85 \pm 0.54 * * * \\
3.144 .62\end{array}$ & $2.34-4.51$ & $1.88-4.51$ & $1.88-4.51$ & $2.2-4.7$ & - & - \\
\hline Length of caudal process, $\mu \mathrm{m}$ & $\begin{array}{c}221.09 \pm 5.83 \\
221.04-234.64\end{array}$ & $\begin{array}{c}194.89 \pm 8.91 * * * \\
180.37-207.12\end{array}$ & $190-210$ & $175-210$ & - & $350-1900$ & - & - \\
\hline $\begin{array}{l}\text { Width of caudal process in the } \\
\text { middle, } \mu \mathrm{m}\end{array}$ & $\begin{array}{l}13.48 \pm 1.03 \\
11.08-14.85\end{array}$ & $\begin{array}{c}14.39 \pm 0.80 * \\
12.19-15.07\end{array}$ & - & $13-18$ & - & - & - & - \\
\hline Length of eggs in uterus, $\mu \mathrm{m}$ & $\begin{array}{l}108.66 \pm 8.92 \\
90.45-120.87\end{array}$ & $\begin{array}{l}110.53 \pm 9.08 \\
93.12-122.66\end{array}$ & $95-103$ & $95-115$ & $95-115$ & $80-110$ & - & $\begin{array}{c}100 \\
90-120\end{array}$ \\
\hline Width of eggs in uterus, $\mu \mathrm{m}$ & $\begin{array}{l}45.20 \pm 1.69 \\
41.21-47.43\end{array}$ & $\begin{array}{c}45.11 \pm 1.64 \\
4.05-47.43\end{array}$ & 43 & $43-56$ & $43-56$ & $40-50$ & - & $\begin{array}{c}51 \\
42-59\end{array}$ \\
\hline Width of shell of eggs in uterus, $\mu \mathrm{m}$ & $\begin{array}{c}2.07 \pm 0.15 \\
1.88-2.28\end{array}$ & $\begin{array}{c}2.08 \pm 0.09 \\
1.95-2.22\end{array}$ & - & - & - & - & - & - \\
\hline
\end{tabular}

Note: “_“- parameters were not defined; *-P $<0.05 ;{ }^{* *}-\mathrm{P}<0.01$; ***-P $<0.001$ compared with values of parameters of short-tailed females.

The short-tailed and long-tailed morphotypes of females were significantly different in most measurements, especially in the size of the tail end. In long-tailed this figure was $3.8 \pm 0.5 \mathrm{~mm}$, which is $43.6 \%$ more $(\mathrm{P}<$ $0.001)$ than in short-tailed $(2.2 \pm 0.2 \mathrm{~mm})$. Thus, long-tailed females were larger by $19.1 \%(12.5 \pm 0.5 \mathrm{~mm}, \mathrm{P}<0.001)$ than short-tailed $(10.08 \pm$ $0.81 \mathrm{~mm})$. The body width in long-tailed female nematodes in different parts of the body was also higher by seven indicators (by 4.7-21.2\%, P< 0.001). In long-tailed females, the oral capsule was deeper (by $23.2 \%, \mathrm{P}<$ 0.001 ), and the distance from the head end to the nerve ring was longer (28.9\%, $\mathrm{P}<0.001)$ compared with short-tailed females. The structural elements of the esophagus and parameters of its length and width were higher in five indicators (by $3.2-26.4 \%, \mathrm{P}<0.001-0.01$ ). At the same time, the bulb of the esophagus in short-tailed animals was wider (by $13.9 \%, \mathrm{P}<0.001$ ) than in long-tailed ones. The vulva in long-tailed females was located at a greater distance from the head and tail ends (by $11.5 \%$ and $20.6 \%$, respectively) compared with similar indicators in shorttailed females. Notably, the caudal process was shorter (by $11.9 \%, \mathrm{P}<$ 0.001 ) in long-tailed females than in short-tailed females, and the width in its middle part was larger (by $6.3 \%, \mathrm{P}<0.05$ ). At the same time, the size of the eggs in the uterus did not have significant differences in females of both morphotypes. In total, we proposed using 25 morphometric parameters to identify female $P$. ambiguus, which characterize the length and 
width of the body in different parts, the size of the esophagus and its internal structure, the depth of the oral capsule, location, nerve ring, vulva and anus, tail end size and appendix.

\section{Discussion}

Most scientific studies indicate a significant prevalence, up to $75 \%$, of passaluriasis among the population of both domestic and wild rabbits and hares, in many countries (Frank et al., 2013; Motamedi et al., 2014; Abdel-Gaber et al., 2019; Hajipour \& Zavarshani, 2020). Therefore, diagnosing this infection and improving the approaches to the identification of P. ambiguus is an important area of research. This relevance is due to the fact that some authors indicate difficulties in identifying species of P. ambiguus and P. nonanulatus (Hugot et al., 1982; Bin \& Chunsheng, 1987).

The morphological study of isolated $P$. ambiguus nematodes reveals that the general differential species features include: the structure of the head end (simple mouth, the presence of four head papillae and three teeth), esophagus (the presence of cylindrical and bulbous sections with two narrowed areas). In males, the characteristic morphological features are the hook-shaped body, the presence of one wide and short spicule with a handle, the tail papillae surrounding the anus, the characteristic structure of the tail end (the presence of narrow wings and papillary protrusions). In females, the characteristic morphological features are the shape of the vulva, the presence of verrucose formations in the vulva, the characteristic structure of the tail (shape, structure). The data obtained on important differential features of $P$. ambiguus are consistent with most studies conducted using both light microscopy and scanning electron microscopy (Hugot et al., 1982; Vicente et al., 1997; Pinto et al., 2004). At the same time, there are reports of lip presence in P. ambiguus (Bin \& Chunsheng, 1987). However, according to the authors, this error is related to the perception of such structural elements as the head papillae and teeth as a morphological feature of the lips (Abdel-Gaber et al., 2019).

Based on metric studies of mature males and females of P. ambiguns, we propose to determine a larger number of parameters that will allow more effective identification of these pathogens. The obtained results were compared with the published data proposed by the authors for the identification of $P$. ambiguus. In males, we proposed using 28 morphometric parameters for species identification. The number of parameters proposed by other authors ranged from one to 10 , including the total body length of males, the distance from the head to the nerve ring, maximum body width, total length of the esophagus, length and width of the cylindrical esophagus and bulb, distance from the cloaca to the tail end, the length of the narrowed part of the tail, the width of the narrowed part of the tail in the area of the papillary protrusions and the total length of the spicule. Moreover, our data and the results of other authors are somewhat different (Hall, 1916; Skryabin et al., 1960; Gvozdev et al., 1970; Hugot et al., 1983; Frank et al., 2013; Boyko et al., 2019; Gugosyan et al., 2019; Mykhailiutenko et al., 2019). This difference may be due, in our opinion, to the morphological adaptation of pathogens to ever-changing living conditions. Therefore, we propose using additional metric parameters, which characterize the depth of the oral capsule, body width in different parts, structure of esophagus, location of the cloaca relative to the head end, shape of the proximal and distal ends of the spicule and its handle, to identify male P. ambiguous.

To effectively identify females of $P$. ambiguus, it is proposed to use 25 morphometric parameters. Other authors proposed from one to eight parameters for the differential diagnosis of females $P$. ambiguous, including the total body length of females, the distance from the head to the nerve ring, maximum body width and body width in vulva area, the total length of the esophagus, the length and width of the cylindrical part of the esophagus, the distance from the vulva to the head and tail ends, the length of the tail end, the length and width of the caudal process. Our data on several of those indicators also differ from the results obtained by other authors (Hall, 1916; Skryabin et al., 1960; Gvozdev et al., 1970; Hugot et al., 1983; Frank et al., 2013; Mykhailiutenko et al., 2019). In particular, some authors note that the bulb in females has a spherical structure and propose to measure its diameter (Hall, 1916; Skryabin et al., 1960). According to our research, the bulb has a more elongated shape and, there- fore, we propose measuring both its length and width. Therefore, we additionally proposed using metric parameters to identify female $P$. ambiguus, which characterize the depth of oral capsule, body width in different parts of the body, the size of the narrowings in the esophagus, the distance from vulva to anus.

Our morphometric studies revealed two morphotypes of mature females of $P$. ambiguns, which differed in the size of the tail end. The length of long-tailed females was $43.6 \%$ longer $(\mathrm{P}<0.001)$ than that of shorttailed females. It was also proved that according to 19 indicators longtailed females were significantly larger than short-tailed, namely by the body length and width in different areas, depth of the oral capsule, size of the esophagus and its structural elements, distance from vulva to head and tail ends, distance from the head end to the nerve ring, the width of the caudal process. At the same time, short-tailed females were larger than the long-tailed females by two indicators (length of esophageal bulb and caudal process). It should be noted that the size of the eggs in the uterus were the same in females of both morphotypes.

Therefore, our data indicate the need for further molecular genetic studies on the identified morphotypes of females, which have significant metric differences. The use of the proposed morphometric parameters for the identification of $P$. ambiguns, taking into account the determined morphotypes of females, will facilitate the differential species diagnosis of these parasites.

\section{Conclusion}

It is proposed to use additional morphometric parameters to enhance the efficiency of the differential diagnosis in order to morphologically identify the nematodes of the species Passalurus ambiguus (Rudolphi, 1819) isolated from the colon of domestic rabbits (Oryctolagus cuniculus domesticus). 28 parameters are proposed in male nematodes and 25 in female nematodes to characterize the total length of the body, its width in different areas, the depth of the oral capsule, the size of the esophagus and its structural elements, the location of the nerve ring. Additional parameters in males characterize the location of the cloaca and the shape and structure of the spicule. Female-specific characters are pointed out that determine the location of the vulva, anus, tail length and caudal process and its width. The isolated females of $P$. ambiguus are represented by two morphotypes (short-tailed and long-tailed), which differ significantly in size by 21 morphometric parameters. The main difference in morphological features of female morphotypes was the difference in tail length. The long-tailed females were larger by 19 indicators (body length, width in different areas, depth of the oral capsule, size of the esophagus and its structural elements, location of the vulva and nerve ring, width of the caudal process) and smaller by two parameters (length of the esophageal bulb, the length of the caudal process) than short-tailed nematodes.

\section{References}

Abdel-Gaber, R., Ataya, F., Fouad, D., Daoud, M., \& Alzuhairy, S. (2019). Prevalence, morphological and molecular phylogenetic analyses of the rabbit pinworm, Passalurus ambiguus Rudolphi 1819, in the domestic rabbits Oryctolagus cuniculus. Acta Parasitologica, 64(2), 316-330.

Ashmawy, K. I., El-Sokkary, M. Y., Abu-Akkada, S. S., \& Dewair, A. W. (2010). Incidence of Passalurus ambiguus in domestic rabbits in Behera Province. Austral Journal of Veterinary Sciences, 30, 115-120.

Bin, Z., \& Chunsheng, B. (1987). Scanning electron microscopic observations of the integumental surface of adult Passalurus ambiguus. Acta Zoologica Sinica, 33(4), 383-384.

Boag, B., \& Iason, G. (1986). The occurrence and abundance of helminth parasites of the mountain hare Lepus timidus (L.) and the wild rabbit Oryctolagus cuniculus (L.) in Aberdeenshire, Scotland. Journal of Helminthology, 60(2), 92-98.

Boyko, O. O., Gugosyan, Y. A., Shendrik, L. I., \& Brygadyrenko, V. V. (2019). Intraspecific morphological variation in free-living stages of Strongyloides papillosus (Nematoda, Strongyloididae) parasitizing various mammal species. Vestnik Zoologii, 53(4), 313-324.

Cullere, M., \& Dalle Zotte, A. (2018). Rabbit meat production and consumption: State of knowledge and future perspectives. Meat Sience, 143, 137-146.

Dalle Zotte, A. (2014). Rabbit farming for meat purposes. Animal Frontiers, 4, 62-67.

Danheim, B. L., \& Ackert, J. E. (1929). On the anatomy of the nematode Passalurus ambiguus (Rudolphi). Transactions of the American Microscopical Society, 48, $80-85$. 
Ebino, K. Y., Shutoh, Y., \& Takahashi, K. W. (1993). Coprophagy in rabbits: Autoingestion of hard feces. Jikken Dobutsu. Experimental Animals, 42(4), 611-613.

Eira, C., Torres, J., Miquel, J., \& Vingada, J. (2007). The helminth parasites of the wild rabbit Oryctolagus cuniculus and their effect on host condition in Dunas de Mira, Portugal. Journal of Helminthology, 81(3), 239-246.

Eslami, A., Changizy, E., \& Moghadam, M. (2000). Prevalence of helminth infections in the cape hare (Lepus capensis) in Iran. Veterinary Research Communications, 24(7), 455-458.

Fayek, S. A., El Bahy, N. M., \& El Khair, A. (1995). Contributions on the Passalurus ambiguus life cycle and scanning electron microscopy studies. Veterinary Medical Journal, 43(4), 449-453.

Foronda, P., Valladares, B., Lorenzo-Morales, J., Ribas, A., Feliu, C., \& Casanova, J. C. (2003). Helminths of the wild rabbit (Oryctolagus cuniculus) in Macaronesia. Journal of Parasitology, 89(5), 952-957.

Frank, R., Kuhn, T., Mehlhom, H., Rueckert, S., Pham, D., \& Klimpel, S. (2013). Parasites of wild rabbits (Oryctolagus cuniculus) from an urban area in Germany, in relation to worldwide results. Parasitology Research, 112(12), 4255-4266.

Georgieva, K., Yoneva, A., Mizinska-Boevska, Y., \& Todev, I. (2005). Ultrastructure of the contact surfaces of Passalurus ambiguus (Rudolphi, 1819) (Nematoda). Acta Biologica Hungarica, 56, 297-303.

González-Acuña, D., Rebolledo, P., Skewes, O., Moreno, L., \& Castro, D. (2005). Parásitos de la liebre (Lepus europaeus Pallas, 1778): Estudio en dos zonas geográficas de Chile. Parasitologia Latinoamericana, 60, 174-177.

Gugosyan, Y. A., Boyko, O. O., \& Brygadyrenko, V. V. (2019). Morphological variation of four species of Strongyloides (Nematoda, Rhabditida) parasitising various mammal species. Biosystems Diversity, 27(1), 85-98.

Gvozdev, E. V., Kontrimavichus, V. L., Ryzhikov, K. M., \& Shaldybin, L. S. (1970). Oprelitel' gel'mintov zajceobraznyh SSSR [Key to the helminth parasites of Lagomorpha in the USSR]. Nauka, Moscow (in Russian).

Hajipour, N., \& Zavarshani, M. (2020). Ectoparasites and endoparasites of New Zealand white rabbits from North West of Iran. Iranian Journal of Parasitology, $15(2), 266-271$.

Hall, M. C. (1916). Nematode parasites of mammals of the orders Rodentia, Lagomorpha, and Hyracoidea. Proceedings of the United States National Museum, 50(2131), 1-258.

Hobbs, R. P., Twigg, L. E., Alliot, A. D., \& Wheeler, A. G. (1999). Evaluation of the associatism of parasitism with mortality of wild rabbits Oryctolagus cuniculus (L.) in South Western Australia. Journal of Parasitology, 85(5), 803-808.

Hugot, J.-P., Bain, O., \& Cassone, J. (1983). Sur le genre Passalurus (Oxyuridae: Nematoda) parasite de Leporidés. Systematic Parasitology, 5(4), 305-316.

Ilić, T., Stepanović, P., Nenadović, K., \& Dimitrijević, S. (2018). Improving agricultural production of domestic rabbits in Serbia by follow-up study of their parasitic infections. Iranian Journal of Veterinary Research, 19(4), 290-297.

Ivashkin, V. M., Kontrimavichus, V. L., \& Nazarova, N. S. (1971). Metody sbora i izuchenija gel'mintov nazemnyh pozvonochnyh [Method for collection and study of helminths of terrestrial vertebrates]. Nauka, Moscow (in Russian).

Kornaś, S., Kowal, J., Wierzbowska, I., Basiaga, M., Nosal, P., \& Niedbała, P. (2015). The alice - "Follow the white rabbit" - parasites of farm rabbits based on coproscopy. Annals of Parasitology, 61(4), 257-261.
Li, S., Cui, P., Fang, S. F., Lin, R. Q., Zou, F. C., \& Zhu, X. Q. (2014). Sequence variability in four mitochondrial genes among rabbit pinworm (Passalurus ambiguns) isolates from different localities in China. Mitochondrial DNA, 26, 501-504.

Li, S., Zeng, W., Li, R., Hoffman, L. C., He, Z., Sun, Q., \& Li, H. (2018). Rabbit meat production and processing in China. Meat Sience, 145, 320-328.

Madsen, M. (1986). A review of various parasites of rabbits. Nordisk Veterinaermedicin, 38(6), 333-351.

Motamedi, G., Moharami, M., Paykari, H., Eslampanah, M., \& Omraninava, A. (2014). A survey on the gastrointestinal parasites of rabbit and guinea pig in a laboratory animal house. Archives of Razi Institute, 69(1), 77-81.

Mykhailiutenko, S. M., Kruchynenko, O. V., Klymenko, O. S., Serdioucov, J. K. Dmytrenko, N. I., \& Tkachenko, V. V. (2019). Pathomorphological changes in the large intestine of rabbits parasitised by Passalurus ambiguus (Nematoda, Oxyuridae). Regulatory Mechanisms in Biosystems, 10(1), 69-74.

Nosal, P., Kowal, J., Nowosad, B., Bieniek, J., \& Kowalska, D. (2009). Dynamics of endoparasite infections in rabbits at different rearing regimes. Wiadomosci Parazytologiczne, 55(2), 173-177.

Pinto, R. M., Gomez, D. C., Menezes, R. C., Gomez, C. T., \& Noronha, D. (2004). Helminths of rabbits (Lagomorpha, Leporidae) deposited in the helminthological collection of the Oswaldo Cruz Institute. Revista Brasileira de Zoologia, 21(3), 599-604

Rinaldi, L., Russo, T., Schioppi, M., Pennacchio, S., \& Cringoli, G. (2007). Passalurus ambiguus: New insights into copromicroscopic diagnosis and circadian rhythm of egg excretion. Parasitology Research, 101, 557-561.

Sheng, L., Cui, P., Fang, S., Lin, R., Zou, F., \& Zhu, X. (2014). Sequence variability in four mitochondrial genes among rabbit pinworm (Passalurus ambiguus) isolates from different localities in China. Mitochondrial DNA, 26(4), 501-504.

Skjabin, K. I., Shikhobalova, N. P., \& Lagodovskaya, E. A. (1967). Osnovy nematodologii. Oksiuraty [Essentials of nematodology. Oxyurates]. Nauka, Moscow (in Russian).

Skrjabin, K. I. (1928). Metod polnyh gel'mintologicheskih vskrytij pozvonochnyh, vkljuchaja cheloveka [The method of complete helminthological autopsy of vertebrates, including humans]. Moscow State University, Moscow (in Russian).

Sultan, K., Elhawary, N. M., Sourour, S. S. G., \& Sharaf, H. (2015). Observations of the rabbit pinworm Passalurus ambiguus (Rudolphi, 1819) in domestic rabbits (Oryctolagus cuniculus) in Egypt using a scanning electron microscope. Tropical Biomedicine, 32(4), 745-752.

Taffs, L. F. (1976). Pinworm infections in laboratory rodents: A review. Laboratory Animals, 10(1), 1-13.

Vicente, J. J., Rodrigues, H. O., Gomes, D. C., \& Pinto, R. M. (1997). Nematóides do Brasil. Parte V: Nematóides de mamíferos. Revista Brasileira de Zoologia, 14(1), 117-120.

Yagoob, G., \& Hossein, H. (2011). Prevalence rate of endoparasites in wild rabbits of East-Azerbaijan Province, Iran. Annals of Biological Research, 2, 31-35.

Yevstafieva, V. O., Prykhodko, Y. O., Kruchynenko, O. V., Mykhailiutenko, S. M., \& Kone, M. S. (2020). Biological specifics of exogenous development of Oxyuris equi nematodes (Nematoda, Oxyuridae). Biosystems Diversity, 28(2), 125-130. 